\title{
Holocene fulgurite formation in the southern Central Sahara (Niger)
}

\author{
B.Sponholz \\ Geographisches Institut, Universität Würzburg, Germany
}

\begin{abstract}
Fulgurites (= natural glasses formed by lightning strikes to the ground) are indicators of thunderstorms (e.g. Julien 1901). The distribution pattern of fulgurites in the study area (Grand Erg de Bilma and Erg de Ténéré between $11.5^{\circ} \mathrm{E}$ and $16.5^{\circ}$ and $18.5^{\circ}$ $\mathrm{N})$ shows decreasing fulgurite concentration from south to north. The fulgurite sites are concentrated in the area of fossil dune complexes, where they occur topographically above palaeolimnic deposits in mid-slope position of interdune depressions.
\end{abstract}

Geomorphological field investigations and optical and chemical analyses on fulgurites lead to the following results:*

- The fulgurite sites characterize a region of important thunderstorm activity and contemporaneous soil humidity in today (hyper-) arid regions.

- The fulgurite rim in mid-slope position around the interdune depressions attest to the former groundwater/lake level.

- However, during the period of fulgurite formation, dry dunes without vegetation cover must have existed in the same area.

- Thunderstorms during which fulgurites have been formed in the study area may be related to an advective "monsoonal" climatic regime that reached up to about $18^{\circ} \mathrm{N}$.

- Related to the results of studies in other domaines, e.g. morph-pedology (Grunert 1988, Völkel 1989), palaeobotany (Neumann 1988, Schulz 1987), palaeoclimatology (Servant 1983, Durand \& Lang 1986), the fulgurites attest to the mid-Holocene climatical conditions in the southern Central Sahara.

* Details of the analytical studies and the discussion of the results are presented in: Sponholz, B., Baumhauer, R. \& P. Felix-Henningsen: Fulgurites in the southern Central Sahara, Republic of Niger, and their palaeoenvironmental significance.- The Holocene, in print.

\section{REFERENCES}

Durand, A. \& J. Lang 1986. Approche critique des méthodes de reconstitution paléoclimatique: le Sahel nigéro-tchadien depuis 40.000 ans. Bulletin de la Societé géologique de France 8 (IL/2): 267-278.

Grunert, J. 1988. Klima- und Landschaftsentwicklung in Ost-Niger während des Jungpleistozäns und Holozäns. Würzburger Geographische Arbeiten 69: 289-304. 
Julien, A.A. 1901. A study of the structure of fulgurites. Journal of Geology 9: 289-304. Neumann, K. 1988. Die Bedeutung von Holzkohleuntersuchungen für die Vegetationsgeschichte der Sahara - Das Beispiel Fachi/Niger.- Würzburger Geographische Arbeiten 69: 71-86.

Schulz, E. 1987. Die holozäne Vegetation der zentralen Sahara (N-Mali, N-Niger, SWLibyen). Palaeoecology of Africa 18: 143-161.

Servant, M. 1983. Séquences du Bassin du Tchad au Cénozoique Supérieur. Travaux et Documents de l'ORSTOM 159: 1-573.

Völkel, J. 1989. Geomorphologische und pedologische Untersuchungen zum jungquartären Klimawandel in den Dünengebieten Ost-Nigers (Südsahara und Sahel). Bonner Geographische Abhandlungen 79: 1-258. 